\title{
Identification of CYP21A2 mutant alleles in Czech patients with 21-hydroxylase deficiency
}

\author{
ZUZANA VRZALOVÁ ${ }^{1}$, ZUZANA HRUBÁ ${ }^{1}$, EVA ST'AHLOVÁ HRABINCOVÁ ${ }^{1}$, SLAVKA POUCHLÁ ${ }^{1}$, \\ FELIX VOTAVA $^{2}$, STANISLAVA KOLOUSKOVÁ ${ }^{3}$ and LENKA FAJKUSOVÁ ${ }^{1,4}$ \\ ${ }^{1}$ Centre of Molecular Biology and Gene Therapy, University Hospital Brno, Cernopolní 9, CZ-62500 Brno; \\ ${ }^{2}$ Department of Pediatrics, Third Faculty of Medicine, Charles University and University Hospital \\ Kralovské Vinohrady, Srobárova 50, CZ-10034 Prague; ${ }^{3}$ Department of Pediatrics, Second Faculty of Medicine, \\ Charles University and University Hospital Motol, V Úvalu 84, CZ-15006 Prague; ${ }^{4}$ Department of \\ Functional Genomics and Proteomics, Institute of Experimental Biology, Faculty of Science, \\ Masaryk University, Kamenice 5, CZ-62500 Brno, Czech Republic
}

Received April 28, 2010; Accepted June 18, 2010

DOI: 10.3892/ijmm_00000504

\begin{abstract}
Congenital adrenal hyperplasia $(\mathrm{CAH})$ is comprised of a group of autosomal recessive disorders caused by an enzymatic deficiency which impairs the biosynthesis of cortisol and, in most of the severe cases, also the biosynthesis of aldosterone. Approximately $90-95 \%$ of all the CAH cases are due to mutations in the steroid 21-hydroxylase gene (CYP21A2). In this study, the molecular genetic analysis of CYP21A2 was performed in 267 Czech probands suspected of 21-hydroxylase deficiency (21OHD). 21OHD was confirmed in 241 probands ( 2 mutations were detected). In 26 probands, a mutation was found only in 1 CYP21A2 allele. A set of 30 different mutant alleles was determined. We describe i) mutated $C Y P 21 A 2$ alleles carrying novel point mutations (p.Thr168Asn, p.Ser169X and p.Pro386Arg), ii) mutated CYP21A2 alleles carrying the novel chimeric gene designated as $\mathrm{CH}-7$, which was detected in $21.4 \%$ of the mutant alleles, iii) an unusual genotype with a combination of the $C Y P 21 A 2$ duplication, 2 point mutations and the CYP21A2 large-scale gene conversion on the second allele, and (iv) a detailed analysis of the chimeric $C Y P 21 A 1 P / C Y P 21 A 2$ genes. In conclusion, our genotyping approach allowed for the accurate identification of the CYP21A2 gene mutations in $210 \mathrm{HD}$ patients and their families and provided some useful information on diagnosis and genetic counselling.
\end{abstract}

Correspondence to: Dr Lenka Fajkusová, Centre of Molecular Biology and Gene Therapy, University Hospital Brno, Cernopolní 9, CZ-62500 Brno, Czech Republic

E-mail: lenkafajkusova@volny.cz

Key words: congenital adrenal hyperplasia, steroid 21-hydroxylase, 21-hydroxylase deficiency, pseudogene, chimeric gene

\section{Introduction}

Congenital adrenal hyperplasia (CAH) is a group of autosomal recessive disorders caused by an enzymatic deficiency which impairs the biosynthesis of cortisol and, in most of the severe cases, also the biosynthesis of aldosterone. Approximately 90-95\% of all the $\mathrm{CAH}$ cases are due to 21 -hydroxylase deficiency (21OHD), and $\sim 5-8 \%$ cases are due to $11-\beta-$ hydroxylase deficiency (1). In the adrenal cortex, the steroid 21-hydroxylase $(21 \mathrm{OH})$ converts 17 -hydroxyprogesterone into 11-deoxycortisol and progesterone into 11-deoxycorticosterone. These steroids are subsequently converted into cortisol and aldosterone, respectively (1).

The steroid $210 \mathrm{H}$ gene $(C Y P 21 A 2)$ and its inactive pseudogene $(C Y P 21 A 1 P)$ are located within the HLA class III region of the major histocompatibility complex locus on chromosome 6p21.3. The CYP21A2 gene is $98 \%$ homologous to the CYP21A1P pseudogene in exons and $96 \%$ in introns $(2,3)$. Together with the neighbouring genes (serine/threonine kinase RP, complement $\mathrm{C} 4$ and tenascin TNX), CYP21 forms a genetic unit termed as the RCCX module $(4,5)$. In the RCCX bimodular haplotype (69\% of chromosome $6 \mathrm{p} 21.3)$, the orientation of genes from telomere to centromere is $R P 1$ C4A-CYP21A1P-TNXA-RP2-C4B-CYP21A2-TNXB. The 3 pseudogenes, $C Y P 21 A 1 P, T N X A$ and $R P 2$, located between the $2 \mathrm{C} 4$ loci, do not encode functional proteins (5).

According to the severity of the disease, 3 clinical forms of $\mathrm{CAH}$ have been distinguished: the classical salt-wasting (SW-CAH), the classical simple virilising (SV-CAH), and the non-classical CAH (NC-CAH) (6). If the patients are not timely diagnosed (by neonatal sreening) and treated, the severe deficiency in $21 \mathrm{OH}$ leads to SW-CAH. In addition to having a severe cortisol deficiency, patients with SW-CAH do not synthesise enough aldosteron and therefore, are not able to maintain sodium homeostasis. Thus, affected patients usually manifest hyponatraemia, hyperkalaemia and vomiting during the first 4 weeks of life. In the female foetus, the excess of androgen causes variable degrees of external genital 
virilisation, and consequently, newborn females have genital ambiguity $(1,7,8)$. The residual activity of $21 \mathrm{OH}$ (aldosterone is synthetized) results in SV-CAH with external genital virilisation in females and also results in signs of precocious pseudopuberty which develop by 8 years of age in female and male patients $(1,8,9)$. NC-CAH is associated with a moderate deficiency in $21 \mathrm{OH}$ and manifests in later childhood or adolescence with hirsutism and decreased fertility or precocious pseudopuberty (8). Patients with NC-CAH secrete aldosterone normally and most of the male patients diagnosed after puberty are entirely asymptomatic $(1,10)$. In order to reduce $\mathrm{CAH}$-associated morbidity and mortality through early diagnosis and treatment, the neonatal screening of CAH based on the detection of 17-hydroxyprogesterone, has been introduced since 2006 in the Czech Republic (11).

The functional CYP21A2 gene and the CYP21A1P pseudogene, each containing 10 exons, are spaced over $3.4 \mathrm{~kb}(2,3)$. The most common source of mutations, involving 95\% of mutant alleles, is the intergenic recombination between CYP21A2 and CYP21A1P, whereas the remaining 5\% of mutant alleles are represented by new mutations. The main CYP21A2 defects are comprised of CYP21A2 deletions, large-scale gene conversions of $C Y P 21 A 2$ into a structure similar to $C Y P 21 A 1 P$, and $C Y P 21 A 1 P / C Y P 21 A 2$ chimeric genes. These mutations are generated by the unequal crossingover during meiosis. However, the mechanism of small-scale gene conversions, that result in short-range mutations in CYP21A2 derived from CYP21A1P, is not yet well understood $(12,13)$. Unequal crossing-over can cause a $30 \mathrm{~kb}$ deletion, involving the $3^{\prime}$ end of $C Y P 21 A 1 P$, all of TNXA, RP2, C4B, and the $5^{\prime}$ end of $C Y P 21 A 2$, which produces a non-functional chimeric gene with $5^{\prime}$ and 3 ' ends corresponding to $C Y P 21 A 1 P$ and CYP21A2, respectively $(14,15)$.

The incidence of classical $\mathrm{CAH}$ in Central Europe is $1 / 10,000$, with a gender ratio of $40 \%$ boys and $60 \%$ girls, and the carrier rate is $1 / 50(7,16)$. The milder, non-classical form of $\mathrm{CAH}$ is much more common, with a prevalence of $1 / 100$ in the general population (8). As CYP21A2 analysis has been made available in many countries, studies on CYP21A2 mutations in large national patient series have provided an insight into specific mutation distributions. In this study, we analyzed $C Y P 21 A 2$ mutations and their frequencies in $210 H D$ patients in the Czech population, and compared the results with previous studies from other countries.

\section{Patients and methods}

Subjects. The patients were sent to our laboratory for the molecular analysis of the CYP21A2 gene after endocrine and clinical evaluation. DNA samples were obtained from peripheral blood leukocytes and/or amniotic fluid by the standard salting-out method. All the studies were approved by the Ethics Board of the University Hospital Brno, and all the patients and their family members gave their written, informed consent for DNA analysis.

Detection of CYP21A2 point mutations derived from CYP21A1P and chimeric CYP21A1P/CYP21A2 genes. The direct screening of $C Y P 21 A 2$ mutations required the specific amplification of the $C Y P 21 A 2$ gene. This step was performed by PCR with primers specific for $C Y P 21 A 2$, which did not allow for the concomitant amplification of CYP21A1P (17). The product of this step was used as the DNA template for the nested amplifications of the CYP21A2 gene fragments carrying the most frequent point mutations. The specific amplification of $C Y P 21 A 2$ was performed by the Expand Long Template System kit (Roche Diagnostics, $\mathrm{GmbH}$ ), and the nested amplifications were performed by Taq DNA Polymerase (Fermentas, GmbH). The PCR primers for the nested PCRs are shown in Table I. The detection of the most common point mutations was performed by long-template PCR and nested PCRs using restriction fragment length polymorphisms (RFLP) (p.Pro30Leu, p.Ser97fsX12, p.Gly110ValfsX21, p.Ile172Asn, p.Val237Glu, p.Val281Leu, p.Gln318X and p.Arg356Trp) and DNA sequencing (p.Leu307PhefsX6) (17). Long-template PCR was also used for the amplification of the chimeric CYP21A1P/CYP21A2 gene. This step was performed using the 5 ' primer specific for $C Y P 21 A 1 P$, and the 3 ' primer specific for CYP21A2 (17). The nested PCRs and RFLPs were applied analogously to the detection of the most common point mutations in order to detect the type of chimeric CYP21A1P/CYP21A2 gene (Fig. 1) (17).

Multiplex ligation-dependent probe amplification (MLPA). MLPA is a method used for the detection of large gene deletions and duplications. For the CAH diagnostics, we used the SALSA MLPA kit P050B CAH (MRS Holland, The Netherlands). This kit contains probes and primers for the analysis of 5 CYP21A2 gene fragments located in the promoter region and exons 3, 4, 6 and 8 . The established MLPA method detects deletions and duplications of the CYP21A2 gene, as well as particular $C Y P 21 A 2$ point mutations, provided that these mutations are located at probe binding sites (p.Gly110ValfsX21, p.Thr168Asn, p.Ser169X, p.Ile172Asn, p.Val237Glu, p.Arg316X and p.Gln318X). Additionally, the MLPA kit contains $28 C Y P 21 A 2$ non-specific probes that are the control standards and sets for the amplification of adjacent genes (CREBL, C4B and TNXB) and pseudogenes (C4A and $T N X A$ ). The assay was performed according to the manufacturer's recommendations. Genomic DNA (200 ng) was denatured at $98^{\circ} \mathrm{C}$ for $5 \mathrm{~min}$, hybridised overnight at $60^{\circ} \mathrm{C}$ with the SALSA probemix, and treated with the Ligase- 65 enzyme at $54^{\circ} \mathrm{C}$ for $15 \mathrm{~min}$. The reactions were stopped by incubation at $98^{\circ} \mathrm{C}$ for $5 \mathrm{~min}$. Subsequently, PCRs were performed with the specific SALSA PCR primers (cycling conditions were 35 cycles at $95^{\circ} \mathrm{C}$ for $30 \mathrm{sec}, 60^{\circ} \mathrm{C}$ for $30 \mathrm{sec}$, and $72^{\circ} \mathrm{C}$ for $60 \mathrm{sec}$ ). The amplification products were run on the CEQ 8000 Genetic Analyzer (Beckman Coulter). Two healthy men were included in every analysis as the controls. The peak height of each analysed fragment was normalised to the peak height of the control sample. Relative peak heights were reduced to $40-60 \%$ with deletions and increased by $30-50 \%$ with duplications.

The results obtained by MLPA were correlated with the results obtained using long-template PCR, nested PCRs, RFLP and/or DNA sequencing. Identified mutations of the CYP21A2 gene were also confirmed by the segregation of the parents' alleles. Detected $C Y P 21 A 2$ deletions can also pose CYP21A2 large-scale conversions into a structure similar to 
Table I. Primers used for the amplification of the CYP21A2 gene.

\begin{tabular}{|c|c|c|}
\hline Primers & Localization & Sequence direction (5'- 3') \\
\hline $30 \mathrm{~F}$ & Promoter & CAGTCTACACAGCAGGAGGGATGGC \\
\hline $30 \mathrm{R}$ & Exon 1 & AGCAAGTGCAAGAAGCCCGGGGCAAGCTG \\
\hline $97 / 110 \mathrm{~F}$ & Intron 2 & ATCAGTTCCCACCCTCCAGCCCCGA \\
\hline 97/110R & Exon 3 & AGGGCTGAGCGGGTGAGCTTC \\
\hline $172 \mathrm{~F}$ & Exon 4 & GAGGAATTCTCTCTCCTCACCTGCAGCATTA \\
\hline $172 \mathrm{R}$ & Intron 4 & AGTTGTCGTCCTGCCAGAAAAGGA \\
\hline $236 / 237 / 239 \mathrm{~F}$ & Exon 6 & AGCAGGCCATAGAGAAGAGGGATCACATCG \\
\hline $236 / 237 / 239 \mathrm{R}$ & Intron 6 & ATGCAAAAGAACCCGCCTCATAGC \\
\hline $281 \mathrm{~F}$ & Exon 7 & TGCAGGAGAGCCTCGTGGCAGG \\
\hline $281 \mathrm{R}$ & Exon 7 & GACGCACCTCAGGGTGGTGAAG \\
\hline $318 / 356 \mathrm{~F}$ & Intron 7 & GCTGGGGCAGGACTCCACCCGA \\
\hline $318 / 356 \mathrm{R}$ & Exon 8 & GTGGGGCAAGGCTAAGGGCACAACTGGC \\
\hline $1 \mathrm{R}^{*}$ & Intron 1 & AAGCAGCGTCAGCGGAGAGGG \\
\hline $2 \mathrm{~F}^{*}$ & Intron 1 & TTGAGGCTGAGGTGGGAGGA \\
\hline $2 \mathrm{R}^{*}$ & Intron 2 & GCGGAGGTGACGGAGAGGGT \\
\hline $3 \mathrm{~F}^{*}$ & Intron 2 & AAGCTCTTGGGGGGCATATC \\
\hline $3 \mathrm{R}^{*}$ & Intron 3 & GGCTACTGTGAGAGGCGAGG \\
\hline $4 \mathrm{~F}^{*}$ & Intron 3 & GTCAGCCTCGCCTCTCACAG \\
\hline $4 \mathrm{R}^{*}$ & Intron 4 & CAGTTCAGGACAAGGAGAGGCT \\
\hline $5 \mathrm{~F}^{*}$ & Intron 4 & AGCCCСТCССТGAGCCTCTC \\
\hline $5 \mathrm{R}^{*}$ & Intron 5 & AGCCTCTCССТCCACCCCAG \\
\hline $6 \mathrm{~F}^{*}$ & Intron 5 & TGGGTTGTAGGGGAGAGGCT \\
\hline $6 \mathrm{R}^{*}$ & Intron 6 & TAGCAATGCTGAGGCCGGTA \\
\hline $7 \mathrm{~F}^{*}$ & Intron 6 & TGCCACTCTGTACTCСТCTC \\
\hline $7 \mathrm{R}^{*}$ & Intron 7 & ACAGTGCTCAGAGCTGAGTG \\
\hline $8 \mathrm{~F}^{*}$ & Intron 7 & CTCACCGGCACTCAGGCTCA \\
\hline $8 \mathrm{R}^{*}$ & Intron 8 & AAGGGGGCTGGAGTTAGAGGCT \\
\hline $9 \mathrm{~F}^{*}$ & Intron 8 & AGTGAGGAAAGCCCGAGCCC \\
\hline $9 \mathrm{R} *$ & Intron 9 & GTGGGTGGGGAGGCGTTCAG \\
\hline $10 \mathrm{~F}^{*}$ & Intron 9 & AAAATGTGGTGGAGGCTGGT \\
\hline $10 R^{*}$ & 3'UTR & ACGGGAGCAATAAAGGAGAAAC \\
\hline RM1F & Promoter & TTCAGGCGATTCAGGAAGGC \\
\hline RM1R & Exon 3 & CTTTCCAGAGCAGGGAGT \\
\hline RM2F & Exon 3 & CGGACCTGTCCTTGGGAGACTAC \\
\hline RM2R & 3'UTR & TTTCAGCCCCACAGTGTAACAGG \\
\hline
\end{tabular}

F, forward primer; R, reverse primer. *Primers used for PCR-sequencing. No $\left(^{*}\right.$ ) primers used for PCR-RFLP (the names of the primers are consistent with the no. of codons carrying an analysed mutation, and primer $30 \mathrm{~F}$ was also used as the forward primer for the sequencing of exon 1). The RM primers were used for the specific amplification of CYP21A2 in order to perform the sequencing analysis of individual exons. For the cDNA reference sequence go to, http://www.ncbi.nlm.nih.gov/nuccore/187895.

CYP21A1P. This type of CYP21A2 deletion was verified by PCR with primers specific to the TNXB/TNXA hybrid gene. (see below) (16).

Detection of CYP21A2 large-scale conversions into CYP21A1P associated with the TNXB/TNXA hybrid gene. The TNXB/TNXA hybrid gene was detected using PCR with the 5' primer specific to $T N X B$ and the 3 ' primer specific to the both genes, TNXB and TNXA (16). In the presence of the TNXB/TNXA hybrid gene, the PCR product sized $2688 \mathrm{bp}$ was generated in contrast to the PCR product sized $2808 \mathrm{pb}$ resulting from the $T N X B$ gene (for the schematic presentation see ref.16).
Detection of rare mutations in the CYP21A2 gene. DNA sequencing was applied for the detection of rare CYP21A2 mutations in patients with a mutation identified only in 1 CYP21A2 allele after basic DNA diagnosis, which included the detection of i) 9 point mutations derived from $C Y P 21 A 1 P$, ii) chimeric genes, and iii) $C Y P 21 A 2$ deletions and duplications. As $90-95 \%$ of the mutant alleles carried $\geq 1$ discrete mutation, the samples carrying none of these mutations were presumed to be unaffected with $>99 \%$ confidence (1). As a primary template for this analysis, we did not use longtemplate PCR product (see the detection of $C Y P 21 A 2$ point mutations derived from $C Y P 21 A 1 P$ and chimeric $C Y P 21 A 1 P /$ $C Y P 21 A 2$ genes) as various polymorphisms were identified 

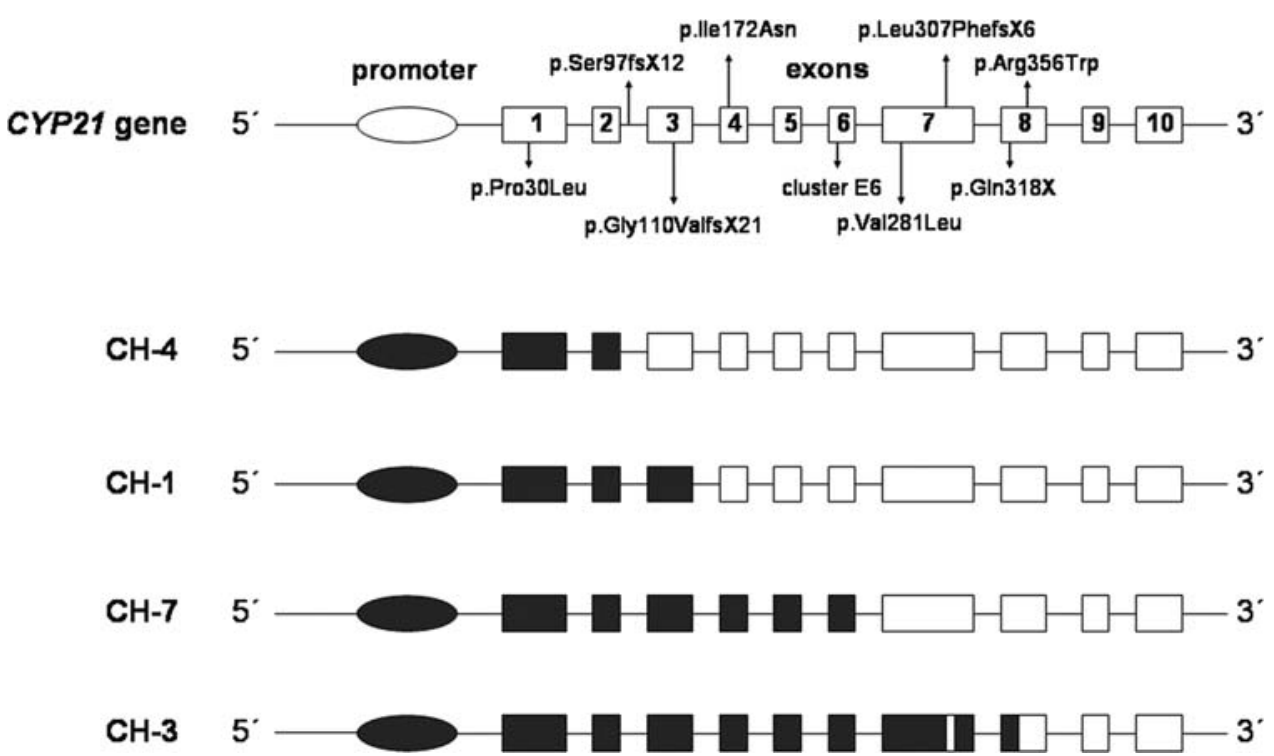

Figure 1. Types of chimeric $C Y P 21 A 1 P / C Y P 21 A 2$ genes identified in the Czech $210 H D$ patients. White boxes, structure of the functional $C Y P 21 A 2$ gene; black boxes, non-functional $C Y P 21 A 1 P$ pseudogene; arrows, mutations existing in $C Y P 21 A 1 P$. From $C Y P 21 A 1 P$, the chimeric gene, CH-4, harbours the promoter, exon 1 (p.Pro30Leu) and exon 2. The chimeric gene, CH-1, bears exon 1, exon 2 (p.Ser97fsX12) and exon 3 (p.Gly110ValfsX21). The chimeric gene, CH-7, carries the promoter, exons 1-3, exon 4 (p.Ile172Asn), exon 5 and exon 6 (p.Ile236Asn, p.Val237Glu, Met239Lys). The chimeric gene, CH-3, harbours the promoter, exons 1-6, exon 7 (p.Leu307PhefsX6, but not Val281Leu) and exon 8 (p.Gln318X).

in the annealing sequences of the $C Y P 21 A 2$ specific primers in some patients. For this reason, the detection of rare mutations was performed with 2 primary PCRs (primers are marked RM1 and RM2, Table I). The first amplified fragment was comprised of a region from the promoter to exon 3 , and the second one of a region from exon 3 to 3'UTR. Both PCRs used $C Y P 21 A 2$ specific primers which were complementary to an 8-bp segment in exon 3 deleted in CYP21A1P (18). PCR products were used as DNA templates for nested amplifications using sequencing primers (Table I). For the localization of primers for primary PCRs inside exon 3, DNA sequencing of this exon was performed using PCR product from longtemplate PCR (17). All the amplifications were performed by Taq DNA Polymerase (Fermentas). The purified PCR products were subsequently sequenced by the BigDye Terminator kit (Applied Biosystems) and analysed on an ABI PRISM 310 sequencer (Applied Biosystems).

\section{Results}

The molecular genetic analysis of the CYP21A2 gene was performed in $267 \mathrm{Czech}$ probands suspected of $21 \mathrm{OHD}$. The diagnosis was confirmed in 241 of them (2 CYP21A2 mutations were found). In 26 probands, a mutation was determined in only 1 CYP21A2 allele (7 patients had SW-CAH, 8 had $\mathrm{SV}-\mathrm{CAH}$ and 11 had NC-CAH). In the set of 21OHD probands, we determined 30 different mutant alleles (Table II).

CYP21A1P/CYP21A2 chimeric genes. The most frequent mutation, the chimeric $C Y P 21 A 1 P / C Y P 21 A 2$ gene, was found in $33.7 \%$ of mutant alleles. Four types of chimeric $C Y P 21 A 1 P /$ CYP21A2 genes were detected in the Czech patients: $\mathrm{CH}-1$, $\mathrm{CH}-3, \mathrm{CH}-4$ and $\mathrm{CH}-7$ (Fig. 1). All the hybrid genes had a different extent of the CYP21A1P sequence attached to the $3^{\prime}$ part of CYP21A2. The types $\mathrm{CH}-1, \mathrm{CH}-3$ and $\mathrm{CH}-4$, have been previously described $(12,19)$. The $\mathrm{CH}-4$ type was found in $2.6 \%$ of the mutant alleles. This hybrid molecule differs from the functional $C Y P 21 A 2$ gene by the $C Y P 21 A 1 P$ promoter sequence and the p.Pro30Leu mutation in exon 1 . The $\mathrm{CH}-1$ type is identical to the CYP21A1P gene in the promoter and exons $1-3$, and the mutation p.Ile172Asn is not present in exon 4. This type of chimeric gene was detected in $9.3 \%$ of the mutant alleles. In addition, $1 \%$ of the patients had an atypical mutant allele with $\mathrm{CH}-1$ and the p.Arg356Trp mutation in exon 8. Mutant alleles carrying $\mathrm{CH}-1$ and p.Arg356Trp were confirmed by the segregation of the parents' alleles. The most common type of the chimeric gene was the newly characterized chimeric gene, $\mathrm{CH}-7$ (21.4\% of the mutant alleles). This chimeric gene involved the $C Y P 21 A 1 P$ sequence from the promoter up to exon 6 , and the p.Val281Leu mutation was not present in exon 7 . The least frequent chimeric gene, CH-3 (0.4\% of mutant alleles) was identical to the CYP21A1P pseudogene from the promoter up to exon 8 , and the p.Gln318X mutation was present in the chimeric gene in contrast to the p.Arg356Gln mutation. In all the cases, the mutant $\mathrm{CH}-3$ allele did not contain the p.Val281Leu mutation.

CYP21A2 deletions and duplications. Total deletions of the CYP21A2 gene were detected in $4.9 \%$ of the CYP21A2 mutant alleles. The $C Y P 21 A 2$ large-scale conversions into $C Y P 21 A 1 P$ generating the $T N X B / T N X A$ hybrid gene represent the majority part of these (3.1\% of the mutant alleles). Koppens et al described that $C Y P 21 A 2$ large-scale conversions generating the TNXA/TNXB hybrid gene are associated with a presence of $2 C Y P 21 A 1 P$ pseudogenes on the involved chromosome (13). The presence of 2 copies of the CYP21A1P pseudogenes on 1 chromosome was identified in all the 
Table II. Types of CYP21A2 mutant alleles and their frequency in Czech 21OHD probands.

\begin{tabular}{|c|c|c|c|c|c|c|}
\hline $\begin{array}{l}\text { Mutant } \\
\text { allele }\end{array}$ & $\begin{array}{l}\text { Mutation at } \\
\text { cDNA level }\end{array}$ & $\begin{array}{l}\text { Mutation at } \\
\text { protein level }\end{array}$ & $\begin{array}{l}\text { Localization of } \\
\text { mutation }\end{array}$ & Phenotype & $\begin{array}{l}\text { No. of } \\
\text { alleles }\end{array}$ & $\begin{array}{l}\text { Frequency } \\
\quad(\%)\end{array}$ \\
\hline 1 & $\begin{array}{l}\text { Chimeric } C Y P 21 A 1 P / \\
C Y P 21 A 2 \text { gene }(\mathrm{CH}-4)\end{array}$ & & Promoter - exon 2 & $\mathrm{NC}, \mathrm{SV}$ & 13 & 2,6 \\
\hline 2 & $\begin{array}{l}\text { Chimeric } C Y P 21 A 1 P / \\
C Y P 21 A 2 \text { gene }(\mathrm{CH}-1)\end{array}$ & & Promoter - exon 3 & SW & 42 & 8,3 \\
\hline 3 & $\begin{array}{c}\text { Chimeric } C Y P 21 A 1 P / \\
C Y P 21 A 2 \text { gene }(\mathrm{CH}-1) \\
\text { + p.Arg356Trp }\end{array}$ & & $\begin{array}{c}\text { Promoter - exon } 3 \text {, } \\
\text { exon } 8\end{array}$ & SW & 5 & 1,0 \\
\hline 4 & $\begin{array}{l}\text { Chimeric } C Y P 21 A 1 P / \\
C Y P 21 A 2 \text { gene }(\mathrm{CH}-7)\end{array}$ & & Promoter - exon 6 & SW & 109 & 21,4 \\
\hline 5 & $\begin{array}{l}\text { Chimeric } C Y P 21 A 1 P / \\
C Y P 21 A 2 \text { gene }(\mathrm{CH}-3)\end{array}$ & & Promoter - exon 8 & SW & 2 & 0,4 \\
\hline 6 & CYP21A2 deletion & & CYP21A2 gene & SW & 9 & 1,8 \\
\hline 7 & $\begin{array}{l}C Y P 21 A 2 \text { large-scale } \\
\text { gene conversion }\end{array}$ & & $C Y P 21 A 2$ gene & SW & 16 & 3,1 \\
\hline 8 & $\begin{array}{c}C Y P 21 A 2 \text { duplication } \\
\text { c. } 290-13 \mathrm{~A} / \mathrm{C}>\mathrm{G} \\
\text { c. } 952 \mathrm{C}>\mathrm{T}\end{array}$ & $\begin{array}{c}C Y P 21 A 2 \text { duplication } \\
\text { p.Ser97fsX12, } \\
\text { p.Gln318X }\end{array}$ & $\begin{array}{l}C Y P 21 A 2 \text { gene } \\
\text { Intron } 2, \\
\text { exon } 8\end{array}$ & SW & 2 & 0,4 \\
\hline 9 & c. $89 \mathrm{C}>\mathrm{T}$ & p.Pro30Leu & Exon 1 & $\mathrm{NC}$ & 19 & 3,5 \\
\hline 10 & c. $290-13 \mathrm{~A} / \mathrm{C}>\mathrm{G}$ & p.Ser97fsX12 & Intron 2 & SW & 122 & 24,00 \\
\hline 11 & c.329_336del8 & p.Gly110ValfsX21 & Exon 3 & SW & 6 & 1,2 \\
\hline 12 & c. $503 \mathrm{C}>\mathrm{A}^{*}$ & p.Thr168Asn ${ }^{*}$ & Exon 4 & NC & 1 & 0,2 \\
\hline 13 & c. $507 \mathrm{C}>\mathrm{A}^{*}$ & p.Ser169X* & Exon 4 & SW & 1 & 0,2 \\
\hline 14 & c. $515 \mathrm{~T}>\mathrm{A}$ & p.Ile172Asn & Exon 4 & SV & 57 & 11,2 \\
\hline 15 & c. $841 \mathrm{G}>\mathrm{T}$ & p.Val281Leu & Exon 7 & $\mathrm{NC}$ & 47 & 9,3 \\
\hline 16 & c.918_919insT & p.Leu307PhefsX6 & Exon 7 & SW & 1 & 0,2 \\
\hline 17 & c.946C $>\mathrm{T}$ & p.Arg316X & Exon 8 & SW & 1 & 0,2 \\
\hline 18 & c. $952 \mathrm{C}>\mathrm{T}$ & p.Gln318X & Exon 8 & SW & 18 & 3,5 \\
\hline 19 & c. $1066 \mathrm{C}>\mathrm{T}$ & p.Arg356Trp & Exon 8 & SW & 20 & 3,9 \\
\hline 20 & c. $1067 \mathrm{G}>\mathrm{A}$ & p.Arg356Gln & Exon 8 & SV & 2 & 0,4 \\
\hline 21 & c. $1157 \mathrm{C}>\mathrm{G}^{*}$ & p.Pro386Arg* & Exon 9 & SW & 1 & 0,2 \\
\hline 22 & c.1357C>T & p.Pro453Ser & Exon 10 & NC & 3 & 0,6 \\
\hline 23 & c. $1375 C>T$ & p.Pro459Ser & Exon 10 & SV & 1 & 0,2 \\
\hline 24 & c. $1448 G>C$ & p.Arg483Pro & Exon10 & SV & 2 & 0,4 \\
\hline 25 & $\begin{array}{l}\text { c. } 290 \_13 \mathrm{~A} / \mathrm{C}>\mathrm{G}, \\
\text { c.329_336del8 }\end{array}$ & $\begin{array}{l}\text { p. Ser97fsX12, } \\
\text { p.Gly110ValfsX21 }\end{array}$ & $\begin{array}{l}\text { Intron } 2 \\
\text { exon } 3\end{array}$ & SW & 1 & 0,2 \\
\hline 26 & $\begin{array}{l}\text { c. } 290 \_13 \mathrm{~A} / \mathrm{C}>\mathrm{G}, \\
\text { c. } 329 \_336 \mathrm{del} 8, \\
\text { c. } 515 \mathrm{~T}>\mathrm{A}\end{array}$ & $\begin{array}{c}\text { p.Ser97fsX12, } \\
\text { p.Gly110ValfsX21, } \\
\text { p.Ile172Asn }\end{array}$ & $\begin{array}{c}\text { Intron 2, } \\
\text { exons } 3 \text { and } 4\end{array}$ & SW & 1 & 0,2 \\
\hline 27 & $\begin{array}{l}\text { c. } 707 \mathrm{~T}>\mathrm{A}, \\
\text { c. } 710 \mathrm{~T}>\mathrm{A}, \\
\text { c. } 716 \mathrm{~T}>\mathrm{A}\end{array}$ & $\begin{array}{l}\text { p.Ile236Asn, } \\
\text { p.Val237Glu, } \\
\text { p.Met239Lys }\end{array}$ & Exon 6 & SW & 3 & 0,6 \\
\hline 28 & $\begin{array}{l}\text { c. } 841 \mathrm{G}>\mathrm{T}, \\
\text { c. } 952 \mathrm{C}>\mathrm{T}\end{array}$ & $\begin{array}{l}\text { p.Val281Leu, } \\
\text { p.Gln318X, }\end{array}$ & Exons 7 and 8 & SW & 1 & 0,2 \\
\hline 29 & $\begin{array}{c}\text { c. } 841 \mathrm{G}>\mathrm{T}, \\
\text { c. } 920 \_921 \mathrm{insT}, \\
\text { c.952C }>\mathrm{T}, \text { c.1066C }>\mathrm{T}\end{array}$ & $\begin{array}{c}\text { p.Val281Leu, } \\
\text { p.Leu307PhefsX6, } \\
\text { p.Gln318X, } \\
\text { p.Arg356Trp }\end{array}$ & Exons 7 and 8 & SW & 1 & 0,2 \\
\hline 30 & c. $952 \mathrm{C}>\mathrm{T}, \mathrm{c} .1066 \mathrm{C}>\mathrm{T}$ & $\begin{array}{l}\text { p.Gln318X, } \\
\text { p.Arg356Trp }\end{array}$ & Exon 8 & SW & 1 & 0,2 \\
\hline
\end{tabular}

Rare CYP21A2 mutations (not derived from $C Y P 21 A 1 P$ ) are shown in bold letters. "These are novel mutations, and have not been described previously. 
Table III. Correlation between genotype and phenotype in 142 Czech 21 OHD patients.

\begin{tabular}{|c|c|c|c|c|c|}
\hline Group & Mutant allele 1 & Mutant allele 2 & Phenotype & $\begin{array}{c}\text { No. of } \\
\text { probands }\end{array}$ & $\begin{array}{c}\text { Frequency } \\
(\%)\end{array}$ \\
\hline \multirow[t]{22}{*}{ A } & Chimeric gene & Chimeric gene & SW & 18 & 12.7 \\
\hline & $\mathrm{CH}-4$ & Chimeric gene & SW & 1 & 0.7 \\
\hline & Chimeric gene & $C Y P 21 A 2$ deletion & SW & 2 & 1.4 \\
\hline & $\mathrm{CH}-4$ & CYP21A2 deletion & SW & 3 & 2.1 \\
\hline & Chimeric gene & p.Ser97fsX12 & SW & 13 & 9.2 \\
\hline & Chimeric gene & p.Gly110ValfsX21 & SW & 2 & 1.4 \\
\hline & Chimeric gene & p.Val237Glu & SW & 2 & 1.4 \\
\hline & Chimeric gene & p.Val281Leu* & SW & 1 & 0.7 \\
\hline & Chimeric gene & p.Gln318X & SW & 4 & 2.8 \\
\hline & CYP21A2 deletion & CYP21A2 deletion & SW & 3 & 2.1 \\
\hline & $C Y P 21 A 2$ deletion & dup[p.Ser97fsX12; p.Gln318X] & SW & 1 & 0.7 \\
\hline & CYP21A2 deletion & p.Ser97fsX12 & SW & 6 & 4.2 \\
\hline & p.Pro30Leu* & p.Arg356Trp & SW & 1 & 0.7 \\
\hline & p.Ser97fsX12 & dup[p.Ser97fsX12; p.Gln318X] & SW & 1 & 0.7 \\
\hline & p.Ser97fsX12 & p.Ser97fsX12 & SW & 4 & 2.8 \\
\hline & p.Ser97fsX12 & p.Ser169X & SW & 1 & 0.7 \\
\hline & p.Ser97fsX12 & p.Gln $318 X$ & SW & 3 & 2.1 \\
\hline & p.Ser97fsX12 & p.Arg356Trp & SW & 1 & 0.7 \\
\hline & p.Ser97fsX12 & p.Pro386Arg & SW & 1 & 0.7 \\
\hline & p.Ser97fsX12, p.Gly110ValfsX21 & p.Gly110ValfsX21 & SW & 1 & 0.7 \\
\hline & $\begin{array}{c}\text { p.Val281Leu, p.Leu307PhefsX6, } \\
\text { p.Gln318X, p.Arg356Trp }\end{array}$ & p.Gln $318 X$ & SW & 1 & 0.7 \\
\hline & p.Arg356Trp & p.Arg356Trp & SW & 2 & 1.4 \\
\hline \multirow[t]{4}{*}{$\mathrm{B}$} & Chimeric gene & p.Ser97fsX12 & SW/SV & 4 & 2.8 \\
\hline & CYP21A2 deletion & p.Ser97fsX12 & SW/SV & 1 & 0.7 \\
\hline & p.Ser97fsX12 & p.Ser97fsX12 & SW/SV & 5 & 3.5 \\
\hline & p.Ser97fsX12 & p.Arg356Trp & SW/SV & 3 & 2.1 \\
\hline \multirow[t]{12}{*}{$\mathrm{C}$} & $\mathrm{CH}-4$ & Chimeric gene & SV & 6 & 4.2 \\
\hline & $\mathrm{CH}-4$ & p.Ser97fsX12 & SV & 1 & 0.7 \\
\hline & Chimeric gene & p.Ile172Asn & SV & 11 & 7.7 \\
\hline & Chimeric gene & p.Pro459Ser & SV & 1 & 0.7 \\
\hline & $C Y P 21 A 2$ deletion & p.Ile172Asn & SV & 2 & 1.4 \\
\hline & p.Ser97fsX12 & p.Ile172Asn & SV & 6 & 4.2 \\
\hline & p.Ile172Asn & p.Ile172Asn & SV & 4 & 2.8 \\
\hline & p.Ile172Asn & p.Val237Glu & SV & 1 & 0.7 \\
\hline & p.Ile172Asn & p.Val281Leu & SV & 1 & 0.7 \\
\hline & p.Ile172Asn & p.Arg316X & SV & 1 & 0.7 \\
\hline & p.Ile172Asn & p.Gln $318 X$ & SV & 1 & 0.7 \\
\hline & p.Ile172Asn & p.Arg356Trp & SV & 2 & 1.4 \\
\hline \multirow[t]{12}{*}{$\mathrm{D}$} & $\mathrm{CH}-4$ & $\mathrm{CH}-4$ & $\mathrm{NC}$ & 1 & 0.7 \\
\hline & Chimeric gene & p.Pro30Leu & $\mathrm{NC}$ & 2 & 1.4 \\
\hline & Chimeric gene & p.Thr168Asn & $\mathrm{NC}$ & 1 & 0.7 \\
\hline & $\mathrm{CH}-4$ & p.Val281Leu & $\mathrm{NC}$ & 1 & 0.7 \\
\hline & p.Pro30Leu & p.Pro30Leu & $\mathrm{NC}$ & 1 & 0.7 \\
\hline & p.Pro30Leu & p.Ser97fsX12 & $\mathrm{NC}$ & 1 & 0.7 \\
\hline & p.Pro30Leu & p.Val281Leu & $\mathrm{NC}$ & 1 & 0.7 \\
\hline & p.Ser97fsX12 & p.Val281Leu & $\mathrm{NC}$ & 3 & 2.1 \\
\hline & p.Ile172Asn & p.Val281Leu & $\mathrm{NC}$ & 2 & 1.4 \\
\hline & p.Val281Leu & p.Val281Leu & $\mathrm{NC}$ & 4 & 2.8 \\
\hline & p.Val281Leu & p.Gln318X & $\mathrm{NC}$ & 1 & 0.7 \\
\hline & p.Val281Leu & p.Arg356Trp & $\mathrm{NC}$ & 2 & 1.4 \\
\hline
\end{tabular}

Group A, patients with SW-CAH; group B, patients with indefinite diagnosis, SV or SW-CAH; group C, patients with SV-CAH; group D, patients with $\mathrm{NC}-\mathrm{CAH}$. Chimeric gene, the CYP21A1P/CYP21A2 chimeric gene (CH-1, CH-3 and CH-7 forms are not distinguished here). *Mutation which does not correspond to the patient's phenotype. 
Table IV. CYP21A2 allele frequencies in different European populations.

\begin{tabular}{|c|c|c|c|c|c|c|c|c|c|c|}
\hline $\mathrm{P}$ & TA & $\begin{array}{l}\text { Del/ } \\
\text { con }\end{array}$ & $\begin{array}{l}\text { p.Pro30 } \\
\text { Leu }\end{array}$ & $\begin{array}{l}\text { p.Ser97 } \\
\text { fsX12 }\end{array}$ & $\begin{array}{l}\text { p.Gly } \\
\text { 110Valf } \\
\text { sX21 }\end{array}$ & $\begin{array}{l}\text { p.Ile } \\
172 \\
\text { Asn }\end{array}$ & $\begin{array}{c}\text { p.Val } \\
\text { 281Leu }\end{array}$ & $\begin{array}{l}\text { p.Gln } \\
318 \mathrm{X}\end{array}$ & $\begin{array}{l}\text { p.Arg } \\
\text { 356Trp }\end{array}$ & $\begin{array}{l}\mathrm{T} \\
(\%)\end{array}$ \\
\hline Czech Republic & 508 & 38.6 & 3.5 & 24.0 & 1.2 & 11.2 & 9.3 & 3.5 & 3.9 & 95.2 \\
\hline $\begin{array}{l}\text { Central Europe } \\
(20)\end{array}$ & 696 & 34.1 & 3.7 & 31.2 & 1.0 & 14.5 & 3.4 & 2.6 & 2.4 & 92.9 \\
\hline $\begin{array}{l}\text { Austria } \\
(21)\end{array}$ & 158 & 35.4 & 3.2 & 22.8 & 0.0 & 15.8 & 12.0 & 2.5 & 3.2 & 94.9 \\
\hline $\begin{array}{l}\text { Hungary } \\
(20)\end{array}$ & 270 & 27.1 & 3.0 & 35.9 & 0.0 & 14.1 & 5.6 & 1.9 & 3.0 & 90.6 \\
\hline $\begin{array}{l}\text { Southern Germany } \\
\text { (22) }\end{array}$ & 310 & 29.0 & 2.6 & 30.3 & 1.6 & 19.7 & 2.9 & 4.8 & 4.5 & 95.4 \\
\hline $\begin{array}{l}\text { The Netherlands } \\
\text { (23) }\end{array}$ & 370 & 31.9 & 0.3 & 28.1 & 4.3 & 12.4 & 2.2 & 3.5 & 8.4 & 91.1 \\
\hline $\begin{array}{l}\text { Spain } \\
(24)\end{array}$ & 266 & 5.6 & 1.5 & 6.0 & 1.1 & 2.3 & 63.2 & 2.3 & 0.8 & 82.7 \\
\hline
\end{tabular}

$\mathrm{P}$, population; TA, total no. of alleles; del, deletion; con, conversion; $\mathrm{T}$, total frequency of given mutations.

Czech patients carrying a CYP21A2 large-scale conversion into CYP21A1P.

Duplications of $C Y P 21 A 2$ associated with a mutation on both gene copies, were found in 2 probands $(0.4 \%$ of the mutated alleles). In both cases, the CYP21A2 genes localized on 1 chromosome carried the p.Ser97fsX12 mutation, as well as the p.Gln318X mutation, respectively. The association between the CYP21A2 duplication and the mentioned point mutations was confirmed by the segregation of the parents' alleles.

CYP21A2 point mutations. Small DNA rearrangements of the CYP21A2 gene, derived and non-derived from CYP21A1P, were present in 56.8 and $2.4 \%$ of the mutant alleles, respectively. The most frequent point mutations were p.Ser97fsX12, p.Ile172Asn and p.Val281Leu. We also detected 7 types of alleles with $\geq 2$ mutations in $1 C Y P 21 A 2$ gene.

DNA sequencing of the CYP21A2 exons and adjacent intron regions was performed in 38 probands with 1 identified CYP21A2 mutant allele. Point mutations non-derived from CYP21A1P were found in 12 patients (Table II). Three of the identified point mutations have not been described previously (p.Thr168Asn, p.Ser169X and p.Pro386Arg). Female patient 1 (NC-CAH) is a compound heterozygote for the p.Thr168Asn mutation (the paternal allele), and the chimeric gene $\mathrm{CH}-7$ (the maternal allele). Female patients 2 and 3 carried a phenotype associated with SW-CAH and both sufferred from genital virilisation and a life-threatening saltwasting crisis in the neonatal phase. Patient 2 carried the p.Ser169X mutation, and the p.Ser97fsX12 mutation (DNA of parents was unavailable for analysis). Patient 3 carried the p.Pro386Arg mutation (the paternal allele) and the p.Ser97fsX12 mutation (the maternal allele).

Phenotype-genotype correlations. The correlation between genotype and phenotype was presented for 142 patients
(Table III) in which sufficient clinical and biochemical data were available. Seventy-two patients suffered from the classic SW-CAH form (Group A), 13 had an indefinite phenotype, in that it was impossible to distinguish the SW and SV-CAH form (Group B), 37 suffered from the classic SV-CAH form (Group C), and 20 had the NC-CAH form (Group D). We observed a good correlation between genotype and phenotype. Discrepancies between genotype and phenotype were found in 2 patients with the SW-CAH phenotype (both patients had a mutation associated with the more moderate phenotype). The first patient is a male compound heterozygote for the p.Val281Leu mutation and the chimeric gene, $\mathrm{CH}-7$. The second one is a female compound heterozygote carrying the p.Pro30Leu and the p.Arg356Trp mutations.

\section{Discussion}

The gene encoding the steroid $210 \mathrm{H}$ enzyme, CYP21A2, is considered to be one of the most polymorphic human genes. Point mutations and copy number variations, such as deletions and duplications, have been described in many populations (20-24). Using the analysis of the CYP21A2 gene, we confirmed the referral diagnosis in 241 Czech unrelated patients suspected of 21OHD. CYP21A2 mutations can be predicted to cause a certain phenotype (SW, SV and NC), on the basis of the reduction of $210 \mathrm{H}$ enzymatic activity. As $210 \mathrm{HD}$ is an autosomal recessive disease and most 21OHD patients are compound heterozygotes, the phenotype of a patient should reflect a mutation that is predicted to cause the least severe impairment of enzymatic activity. This approach to phenotype prediction has been shown to be correct, although slight deviations to this correlation exist $(1,23,25)$. We checked for correlations between the genotypes and phenotypes in 142 probands with 21OHD. A discrepancy was observed in 2 patients with SW-CAH. The first one was a male proband carrying the p.Val281Leu mutation (associated with NC- 
$\mathrm{CAH}$ ) (1) and the $\mathrm{CH}-7$ chimeric gene. The second one was a female proband carrying the p.Pro30Leu mutation (associated with NC-CAH) and the p.Arg356Trp mutation (associated with SV-CAH) (1). Both patients suffered from a salt wasting crisis in the neonatal period and were treated with fludrocortisone and hydrocortisone.

Duplications of CYP21A2 associated with a mutation on both gene copies were found in 2 probands. In both cases, the CYP21A2 duplication was associated with the mutations, p.Ser97fsX12 and p.Gln318X (the same mutant allele has been previously described) (24). Both probands with the CYP21A2 duplication, p.Ser97fsX12 and p.Gln318X on 1 allele have SW-CAH phenotypes. The complete genotypes of these patients were dup[p.Ser97fsX12; p.Gln318X]/ p.Ser97fsX12 and dup[p.Ser97fsX12; p.Gln318X]/CYP21A2 deletion. Determination of the genotype, dup[p.Ser97fsX12; p.Gln318X]/CYP21A2 deletion, was quite difficult. Using long-template PCR, nested PCRs, and PCR-RFLP, the mutations, p.Ser97fsX12 and p.Gln318X, were detected and this result was also confirmed by MLPA. MLPA showed 1 copy of exon 8 (the p.Gln $318 X$ mutation was located in the probe binding site), and other $C Y P 21 A 2$ fragments detected by MLPA had normal peak sizes corresponding to 2 CYP $21 A 2$ copies. Thus, we presumed that this patient's genotype was p.Ser97fsX12/p.Gln318X. Using long-template amplification with primers specific to the $T N X$ genes, we discovered the presence of the $T N X B / T N X A$ hybrid gene and thus the presence of the $C Y P 21 A 2$ large-scale conversion into structure similar to $C Y P 21 A 1 P$. In this patient, a rare genotype combination was characterized, which has not been described so far. For the verification and diagnostic accuracy of our DNA, we also performed DNA analyses on the patients' family members. The mutant allele carrying the CYP $21 A 2$ duplication with p.Ser97fsX12 and p.Gln318X was inherited from the mother and the mutant allele with the CYP21A2 deletion was inherited from the father. We then offered the prenatal diagnosis to this family. After DNA analysis of the amniotic fluid, we detected the CYP21A2 duplication and the point mutations, p.Ser97fsX12 and p.Gln318X, (using PCRRFLP and MLPA), and the CYP21A2 large-scale gene conversion.

The most frequent mutations detected in the Czech 21OHD patients were the chimeric $C Y P 21 A 1 P / C Y P 21 A 2$ genes. To date, 6 different chimeric $C Y P 21 A 1 P / C Y P 21 A 2$ genes have been characterized $(12,14,19,26)$ The $\mathrm{CH}-1, \mathrm{CH}-3$ and $\mathrm{CH}-4$ chimeric genes were detected in the Czech population and in addition, 1 novel type (CH-7) was determined (Fig. 1). The 5 untranslated region of the CYP21A2 gene responsible for the transcriptional activity, is located in the first 167 nucleotides upstream of the ATG codon and contains binding sites for the specificity protein, Sp-1, and adrenal-specific protein transcription factors $(27,28)$. In this fragment, the pseudogene promoter differs from the CYP21A2 promoter in 4 nucleotides, located at the $-126,-113,-110$ and -103 positions. These differences cause a lower affinity of the pseudogene promoter to the transcription factors and, consequently, reduce its transcriptional activity to $20 \%$ when compared to the CYP $21 A 2$ gene $(15,29)$. The mutation p.Pro30Leu is associated with $\mathrm{NC}-\mathrm{CAH}$, and reduces the $21 \mathrm{OH}$ activity to $30-40 \%$ of the normal enzyme. In the chimeric gene $\mathrm{CH}-4$, the mutation
p.Pro30Leu, in synergism with the promoter sequence substitutions, can decrease enzyme activity to $4-10 \%$ (30). In the set of our 21OHD probands, we detected 13 patients with at least $1 \mathrm{CH}-4$ chimeric gene. Three probands with the genotype CH-4/CYP21A2 deletion, and 1 proband with the genotype CH-4/CH-7 suffered from SW-CAH, 7 probands suffered from SV-CAH and their genotypes were $\mathrm{CH}-4 / \mathrm{CH}-1, \mathrm{CH}-4 /$ CH-7 and CH-4/p.Ser97fsX12, and 2 probands were clinically diagnosed as NC-CAH and had the genotypes $\mathrm{CH}-4$ / p.Val281Leu and $\mathrm{CH}-4$ in the homozygous state.

Furthermore, we detected 6 types of alleles with $\geq 2$ mutations in 1 CYP21A2 gene. In the case of mutant alleles 25, 26, 27, 29, and 30 (Table II), mutations present in CYP21A1P were probably transferred to $C Y P 21 A 2$ as 1 recombination event. In the case of alleles 3 and 28 , we presume that 2 recombination events took place $(C Y P 21 A 1 P$ mutations lying between transferred mutations are missing in these alleles).

In the set of our 21OHD patients, we detected 1 novel non-sense mutation (p.Ser169X) and 2 novel missense (p.Thr168Asn and p.Pro386Arg) mutations. The p.Thr168Asn mutation is associated with NC-CAH, and the p.Pro386Arg mutation with SW-CAH. A conservation of amino acid residues was determined by Robins et al, based on the comparison of multiple species-specific sequence variants (pig, dog, cow, sheep, mouse, rat, eel, and puffer fish) homologous to the human CYP21A2 (31). Based on this result, both missense mutations (p.Thr168Asn and p.Pro386Arg) are located in a highly conserved region. The p.Thr168Asn mutation is situated in the central part of helix E and p.Pro386Arg in a loop between the B-sheet 1-3 and helix $K^{\prime}$ (31). In addition, the p.Pro386Arg is located in the heme-binding site (31).

CYP21A2 mutations were detected in 508 alleles of unrelated patients suspected of 21OHD. A comparison with mutation frequencies in other European countries showed similar results in general (Table IV), especially with central European countries. In addition, we described i) mutated CYP21A2 alleles carrying novel point mutations (p.Thr168Asn, p.Ser169X and p.Pro386Arg), ii) mutated CYP21A2 alleles carrying the novel chimeric gene designated as $\mathrm{CH}-7$, iii) an unusual genotype with a combination of the CYP21A2 duplication and the CYP21A2 large-scale gene conversion on the second allele, and iv) a detailed analysis of the chimeric $C Y P 21 A 1 P / C Y P 21 A 2$ genes. In conclusion, our genotyping approach allowed for the accurate identification of CYP21A2 gene mutations in 21OHD patients and their families and provided some useful information on diagnosis and genetic counselling.

\section{Acknowledgements}

This study was supported by the Internal Grant Agency of the Czech Ministry of Health (grant nos. NR9308-3 and NS9981-3) and by the Czech Ministry of Education (project nos. LC06023, MSM0021622415 and MSM0021620814).

\section{References}

1. White PC and Speiser PW: Congenital adrenal hyperplasia due to 21-hydroxylase deficiency. Endocr Rev 21: 245-291, 2000. 
2. White PC, Grossberger D, Onufer BJ, et al: Two genes encoding steroid 21-hydroxylase are located near the genes encoding the fourth component of complement in man. Proc Natl Acad Sci USA 82: 1089-1093, 1985.

3. Higashi Y, Yoshioka H, Yamane M, Gotoh O and FujiiKuriyama Y: Complete nucleotide sequence of two steroid 21hydroxylase genes tandemly arranged in human chromosome: A pseudogene and a genuine gene. Proc Natl Acad Sci USA 83: 2841-2845, 1986.

4. Yang Z, Mendoza AR, Welch TR, Zipf WB and Yu CY: Modular variations of the human major histocompatibility complex class III genes for serine/threonine kinase RP, complement component C4, steroid 21-hydroxylase CYP21, and tenascin TNX (the RCCX module). A mechanism for gene deletions and disease associations. J Biol Chem 274: 12147-12156, 1999.

5. Blanchong CA, Zhou B, Rupert KL, et al: Deficiencies of human complement component $\mathrm{C} 4 \mathrm{~B}$ and $\mathrm{C} 4 \mathrm{~B}$ and heterozygosity in length variants of RP-C4-CYP21-TNX (RCCX) modules in caucasians. The load of RCCX genetic diversity on major histocompatibility complex-associated disease. J Exp Med 191: 2183-2196, 2000

6. New MI and Wilson RC: Steroid disorders in children: Congenital adrenal hyperplasia and apparent mineralocorticoid excess. Proc Natl Acad Sci USA 96: 12790-12797, 1999.

7. Kovacs J, Votava F, Heinze G, et al: Lessons from 30 years of clinical diagnosis and treatment of congenital adrenal hyperplasia in five middle European countries. J Clin Endocrinol Metab 86: 2958-2964, 2001

8. Goncalves J, Friaes A and Moura L: Congenital adrenal hyperplasia: Focus on the molecular basis of 21-hydroxylase deficiency. Expert Rev Mol Med 9: 1-23, 2007.

9. Brinkmann AO: Molecular basis of androgen insensitivity. Mol Cell Endocrinol 179: 105-109, 2001

10. New MI: Extensive clinical experience: Nonclassical 21hydroxylase deficiency. J Clin Endocrinol Metab 91: 4205-4214, 2006.

11. Strnadova KA, Votava F, Lebl J, et al: Prevalence of congenital adrenal hyperplasia among sudden infant death in the Czech Republic and Austria. Eur J Pediatr 166: 1-4, 2007.

12. Lee HH, Lee YJ and Lin CY: Pcr-based detection of the CYP21 deletion and TNXA/TNXB hybrid in the RCCX module. Genomics 83: 944-950, 2004.

13. Koppens PF, Hoogenboezem T and Degenhart HJ: Duplication of the CYP21A2 gene complicates mutation analysis of steroid 21-hydroxylase deficiency: Characteristics of three unusual haplotypes. Hum Genet 111: 405-410, 2002.

14. Lee HH: Chimeric CYP21P/CYP21 and TNXA/TNXB genes in the RCCX module. Mol Genet Metab 84: 4-8, 2005.

15. Chang SF and Chung BC: Difference in transcriptional activity of two homologous CYP21A genes. Mol Endocrinol 9: 1330-1336, 1995.

16. Koppens PF, Hoogenboezem T and Degenhart HJ: Carriership of a defective tenascin- $X$ gene in steroid 21-hydroxylase deficiency patients: TNXB-TNXA hybrids in apparent largescale gene conversions. Hum Mol Genet 11: 2581-2590, 2002

17. Lee HH, Chang JG, Tsai CH, Tsai FJ, Chao HT and Chung B: Analysis of the chimeric CYP21P/CYP21 gene in steroid 21hydroxylase deficiency. Clin Chem 46: 606-611, 2000.

18. Wedell A and Luthman H: Steroid 21-hydroxylase deficiency: Two additional mutations in salt-wasting disease and rapid screening of disease-causing mutations. Hum Mol Genet 2 499-504, 1993
19. L'Allemand D, Tardy V, Gruters A, Schnabel D, Krude H and Morel Y: How a patient homozygous for a 30-kb deletion of the C4-CYP 21 genomic region can have a nonclassic form of 21hydroxylase deficiency. J Clin Endocrinol Metab 85: 4562-4567, 2000.

20. Dolzan V, Solyom J, Fekete G, et al: Mutational spectrum of steroid 21-hydroxylase and the genotype-phenotype association in Middle European patients with congenital adrenal hyperplasia. Eur J Endocrinol 153: 99-106, 2005.

21. Baumgartner-Parzer SM, Schulze E, Waldhausl W, et al: Mutational spectrum of the steroid 21-hydroxylase gene in Austria: Identification of a novel missense mutation. J Clin Endocrinol Metab 86: 4771-4775, 2001.

22. Krone N, Braun A, Roscher AA, Knorr D and Schwarz HP: Predicting phenotype in steroid 21-hydroxylase deficiency? Comprehensive genotyping in 155 unrelated, well defined patients from southern Germany. J Clin Endocrinol Metab 85: $1059-1065,2000$

23. Stikkelbroeck NM, Hoefsloot LH, de Wijs IJ, Otten BJ, Hermus AR and Sistermans EA: CYP21 gene mutation analysis in 198 patients with 21-hydroxylase deficiency in The Netherlands: six novel mutations and a specific cluster of four mutations. J Clin Endocrinol Metab 88: 3852-3859, 2003.

24. Loidi L, Quinteiro C, Parajes S, et al: High variability in cyp21a2 mutated alleles in Spanish 21-hydroxylase deficiency patients, six novel mutations and a founder effect. Clin Endocrinol (Oxf) 64: 330-336, 2006.

25. Friaes A, Rego AT, Aragues JM, et al: CYP21A2 mutations in Portuguese patients with congenital adrenal hyperplasia: Identification of two novel mutations and characterization of four different partial gene conversions. Mol Genet Metab 88: 58-65, 2006.

26. Concolino P, Mello E, Minucci A, et al: A new CYP21A1P/ CYP21A2 chimeric gene identified in an Italian woman suffering from classical congenital adrenal hyperplasia form. BMC Med Genet 10: 72, 2009.

27. Kagawa $\mathrm{N}$ and Waterman MR: cAMP-dependent transcription of the human CYP21B (P-450C21) gene requires a cisregulatory element distinct from the consensus cAMPregulatory element. J Biol Chem 265: 11299-11305, 1990.

28. Kagawa N and Waterman MR: Evidence that an adrenal-specific nuclear protein regulates the cAMP responsiveness of the human CYP21B (P450C21) gene. J Biol Chem 266: 11199-11204, 1991.

29. Bristow J, Gitelman SE, Tee MK, Staels B and Miller WL: Abundant adrenal-specific transcription of the human P450c21A 'pseudogene'. J Biol Chem 268: 12919-12924, 1993.

30. Araujo RS, Billerbeck AE, Madureira G, Mendonca BB and Bachega TA: Substitutions in the CYP21A2 promoter explain the simple-virilizing form of 21-hydroxylase deficiency in patients harbouring a P30L mutation. Clin Endocrinol (Oxf) 62: 132-136, 2005

31. Robins T, Carlsson J, Sunnerhagen M, Wedell A and Persson B: Molecular model of human CYP21 based on mammalian CYP2C5: Structural features correlate with clinical severity of mutations causing congenital adrenal hyperplasia. Mol Endocrinol 20: 2946-2964, 2006. 